\title{
Firm size and capital structure: Evidence using dynamic panel data
}

\author{
Víctor M. González \\ Francisco González \\ Department of Business Administration \\ University of Oviedo \\ Spain
}

\begin{abstract}
This paper suggests that the validity of the trade-off (TOT) and pecking-order (POT) theories to explain financing decisions varies among small, medium-sized and large firms. Using dynamic panel data tests on a sample of 3,439 Spanish firms over the period 1995-2003, results are partially consistent with both explanations but suggest a greater validity of pecking-order predictions for small firms. In small firms, the negative influence of profitability and the positive influence of investment opportunities and of intangible assets on firm debt predicted by the POT are heightened. However, no differences are observed between small and large firms in their speed of adjustment to the target leverage as suggested by the TOT.
\end{abstract}

JEL classification: G32.

Keywords: capital structure, firm size, trade-off theory, pecking-order theory.

Corresponding author: Víctor M. González. Department of Business Administration. University of Oviedo. Avda. del Cristo s/n. 33071 Oviedo. SPAIN. Tel.: + 34 985102826; fax: + 34 985103708; E-mail address: vmendez@,uniovi.es 


\section{Introduction}

The finance literature offers two competing but not mutually exclusive models of financing decisions: the trade-off theory (TOT) and the pecking-order theory (POT). The TOT posits that firms maximize their value when the benefits that stem from debt equal the marginal cost of debt. Additionally, the existence of adjustment costs leads to the TOT suggesting a partial adjustment to optimal leverage in each period.

The POT, developed by Myers and Majluf (1984) and Myers (1984), focuses on the information asymmetries that exist between firm insiders and outsiders. Managers use private information to issue risky securities when they are overpriced. Investors are aware of this asymmetric information problem and discount the firm's new and existing risky securities when new issues are announced. Managers anticipate these price discounts and may forego profitable investments if these must be financed with new risky securities. To avoid this distortion of investments decisions, managers prefer to finance projects with retained earnings, which entail no asymmetric information problem as is the case with risky debt. If there is an inadequate amount of retained earnings, then debt financing will be used. As a result, variation in a firm's leverage is driven not by the trade-off model's costs and benefits of debt, but rather by the firm's net cash flows. The POT predicts that debt typically grows when investment exceeds retained earnings and falls when investment is less than retained earnings.

The evidence provided by recent empirical research coincides in underscoring the partial validity of both explanations, but differs when indicating which one is predominant. Whereas Shyam-Sunder and Myers (1999), Colombo (2001), Fama and French (2002), Tong and Green (2005), and Yu and Aquino (2009) obtain results that are consistent with the predominance of the POT, Flannery and Rangan (2006) suggest a greater validity of the TOT. However, Frank and Goyal (2003) and Leary and Roberts (2005) obtain evidence that is favourable to both theories, without highlighting the predominance of either. 
This paper extends the aforementioned evidence by analyzing whether the validity of the two theories is related to firm size in a panel database of Spanish firms over the 1995-2003 period. The importance of firm size would arise from the greater information asymmetries existing in small firms, which might lead to a greater weight of pecking-order explanations in this type of firm. To analyze how the validity of both theories varies with firm size, we study two aspects: 1) we analyze whether the determinants of firm leverage vary across firm size in a way that is consistent with the predictions of the TOT or the POT, and 2) we analyze whether the prediction of the TOT that firms have a target leverage has a different validity among the three groups of firms (small, medium-sized and large). Unlike previous studies, this paper considers not only quoted firms, but also nonpublicly traded firms, providing evidence about the speed of adjustment to the target leverage of the latter.

To account for dynamic processes in firm leverage, we use the generalized-method-of-moments (GMM) estimators developed by Arellano and Bond (1991) for dynamic panel data. GMM models are specifically designed to handle autoregressive properties in firm leverage, the potential endogeneity of the explanatory variables, and the omission of relevant firm-specific characteristics.

The results of the paper indicate that the TOT and the POT complement one another in explaining capital structure decisions in Spanish firms. Our results support the hypothesis that the greater information asymmetries in small firms lead to a greater validity of the prediction of the POT in these firms, since the positive influence of investment opportunities and of intangible assets and the negative influence of profitability predicted by the POT are heightened in small firms. The paper shows that small firms have a similar speed of adjustment to the target leverage to that of large firms.

The rest of the paper is structured as follows. Section 2 discusses the influence of firm size on capital structure and the hypotheses tested in the paper. Section 3 describes the characteristics of the 
database and the methodology employed, while Section 4 discusses the empirical results. Finally, Section 5 presents some conclusions.

\section{Firm size and capital structure theories: Hypotheses}

A large number of papers have suggested that firm size is positively related to the leverage ratio. The rationale underlying this belief is the evidence provided by Warner (1977) and Ang et al. (1982) that the relevance of direct bankruptcy costs decreases as firm value increases, suggesting that the impact of these costs on the borrowing decisions of large firms might be negligible. It is also argued that larger firms are more diversified (Titman and Wessels, 1988), have easier access to the capital markets, and borrow at more favorable interest rates (Ferri and Jones, 1979). Larger firms with less volatile benefits also have a greater likelihood of being able to fully use tax shields from interest payments, thus increasing the expected tax benefits of debt (Smith and Stulz, 1985). The conflicts between creditors and shareholders are more severe for small firms, however, because the managers of such firms tend to be large shareholders and are better able to switch from one investment project to another (Grinblatt and Titman, 1998). Informational asymmetries between insiders in a firm and the capital markets are higher for small firms (Harris and Raviv, 1991). According to these arguments, most empirical studies in fact report a positive sign for the relationship between size and leverage (Rajan and Zingales, 1995; Frank and Goyal, 2003; Gaud et al., 2005; and López-Iturriaga and Rodríguez-Sanz, 2008).

Although the influence of size on firm debt has been widely analyzed, no study has been carried out to ascertain whether the validity of the TOT and the POT varies with firm size. However, arguments exist that suggest that size is related to the information asymmetry problems that the POT rests on. Larger firms usually have lower information asymmetries. Larger listed firms are required to submit information to the stock exchange and financial analysts monitor these firms on a regular basis, whereas small non-listed firms are only required to produce a straightforward annual report once a year and are rarely monitored by analysts. Credit rating agencies also monitor the solvency of large 
firms and reduce information asymmetries between the firm and outside investors. The exposure of large listed firms reduces the information opacity for these firms compared with smaller non-listed firms. To derive our hypotheses, we assume that with no information asymmetry the POT does not survive and only the TOT applies, whereas the greater the information asymmetry, the greater the validity of the propositions of the POT. This argument leads to our main hypothesis:

\section{H.1. The validity of the predictions of the POT (TOT) is negatively (positively) related to firm size.}

In order to test this hypothesis, we first analyze how the two theories differ as regards the determinants of firm leverage, and secondly how both theories differ with respect to the existence of a leverage target in the firm.

\subsection{Determinants of debt ratio under the TOT and the POT}

As potential determinants of firm leverage, we consider the same variables as Rajan and Zingales (1995) have shown to influence firm leverage in 7 countries: non-debt tax shield, profitability, growth opportunities, and intangibility of assets.

\section{a) Non-debt tax shields}

The TOT predicts that companies have an incentive to take debt because they can benefit from the tax shield. However, if firms have non-debt tax shields (NDTS), such as depreciation and investment tax credits, they have a lower incentive to use debt from a tax shield point of view and hence use less debt (Graham, 2000). The trade-off explanation therefore predicts a negative coefficient for NDTS in the equation explaining firm leverage. Following Titman and Wessels (1988), we measure NDTS as earnings before taxes minus the ratio between taxes paid and the tax rate. 


\section{b) Profitability}

In the TOT, a positive relationship between a firm's profitability and debt is expected because taxes, agency costs, and bankruptcy costs push more profitable firms towards higher leverage. More profitable firms should prefer debt so as to benefit from the tax shield. Moreover, when firms are profitable, all things being equal, they increase their free cash flow and the marginal benefit of using debt to discipline managers. Finally, an increase in profitability reduces the likelihood of firm bankruptcy and the cost of financial distress originated by the use of debt. All these reasons thus lead the TOT to predict a positive relationship between profitability and debt.

According to the POT, the opposite relationship is expected: Firms passively accumulate retained earnings, becoming less levered when they are profitable. All things being equal, the more profitable the firms are, the more internal financing they will have, and therefore we should expect a negative relationship between leverage and profitability. This negative relationship is one of the most systematic findings in the empirical literature (Harris and Raviv, 1991; Rajan and Zingales, 1995).

Following Ozkan (2001) and Miguel and Pindado (2001), we proxy profitability (PROFIT) as earnings before interest and taxes (EBIT) plus depreciation expenses and provisions (non-cash deductions from earnings) divided by total assets.

\section{c) Growth opportunities}

The TOT predicts that, controlling for the profitability of assets in place, firms with more investment opportunities have less leverage because: (1) Greater investment opportunities in the firm are associated with a lower free cash flow and less need for the disciplinary role of debt over manager behaviour (Jensen, 1986); (2) Firms with growth opportunities have more agency conflicts between stockholders and bondholders because shareholders in these firms have stronger incentives to underinvest and greater possibilities of risk-shifting substitution (Myers, 1977); (3) Finally, as the 
value of growth opportunities is close to zero in the case of bankruptcy, the cost of financial distress associated with the use of debt will be higher in firms in which investment opportunities represent a greater percentage of the current value of the firm (Myers, 1984; Harris and Raviv, 1991). All these reasons lead the TOT to predict a negative relationship between investment opportunities and debt in the firm. These arguments are consistent with firms using equity to finance their growth (Jung et al., 1996) and with firms with less growth prospects using debt because of its disciplinary role (Jensen, 1986).

In contrast, the POT predicts a positive marginal relation between leverage and growth opportunities because investment opportunities originate strong financing needs and, all things being equal, will lead to the issuing of more debt. Moreover, as information asymmetries with regard to investment opportunities are higher than with respect to assets in place, the POT predicts a higher preference for debt relative to equity in firms with greater growth opportunities. Following Titman and Wessels (1988), growth opportunities (GROWTH) have been measured in this paper as the growth rate of total assets. ${ }^{1}$

\section{d) Intangibility of assets}

According to the TOT, intangibility of assets has an impact on the borrowing decisions of a firm for at least two reasons: 1) intangible assets have a lower value than tangible assets in the case of bankruptcy and thus increase the cost of financial distress associated with the use of debt, and 2) agency costs between stockholders and creditors are greater when the firm does not offer tangible assets as collateral because the probability of risk-shifting by shareholders is solely limited to the assets that are not offered as collateral. Consistent with these arguments, most of the previous evidence highlights a negative relation between intangible assets and the level of debt (Rajan and Zingales, 1995; Frank and Goyal, 2003).

\footnotetext{
1 As non-publicly traded firms are considered, we cannot use the market-to-book value of assets to proxy growth opportunities.
} 
From the POT perspective, firms with more intangible assets are more subject to information asymmetries and will therefore issue debt rather than equity when they need external financing (Harris and Raviv, 1991). For this reason, ceteris paribus profitability and investment opportunities, the POT predicts a positive relation between intangibility of assets and firm leverage.

We proxy the intangibility of assets (INTANG) as the ratio between intangible assets and total assets. This variable was used by Titman and Wessels (1988) as an indicator that is negatively related to collateral value.

Given that our basic hypothesis forecasts a greater validity of the POT in smaller firms and that the POT and TOT differ in the predicted influence for profitability, growth opportunities and asset intangibility on firm leverage, we may extend hypothesis H.1. as follows:

H.1.a. The greater predominance of the predictions of the POT in smaller firms leads to forecasting a greater negative influence of profitability and a greater positive influence of investment opportunities and of intangible assets on firm leverage in this type of firm.

\subsection{Target firm leverage and adjustment costs}

The existence of a target leverage that firms wish to maintain in each period is the other difference between the TOT and the POT. Under the TOT, there exists an optimum level of indebtedness resulting from compensating benefits with the costs of debt. As the determinants of the costs and benefits of debt, examined in the previous section, are relatively stable over time, the firm's optimum indebtedness will also be stable. However, as the existence of adjustment costs impedes a complete adjustment, the standard framework adopted for testing the TOT is a partial adjustment model in which the change in leverage partially absorbs the difference between target leverage and lagged leverage. 
In contrast, under the POT there exists no target leverage that firms aim to maintain in each period, but rather leverage varies from one period to another depending on the profitability and investment opportunities in the firm. Thus, higher earnings, ceteris paribus investment opportunities, increase the possibilities of retaining benefits and result in less leverage. Higher investment opportunities, ceteris paribus earnings, result in higher leverage.

The different predictions of the TOT and the POT concerning the existence of a target leverage mean that our main hypothesis (H.1) may be extended in the following way:

H.1.b. The greater predominance of the predictions of the POT in smaller firms will originate a lower or non significant speed of adjustment to the target leverage in this type of firm.

\section{Econometric specification and database}

\subsection{Methodology}

The empirical model proposed in this paper accounts for the potentially dynamic nature of a firm's capital structure. The model tests whether there is a target leverage and, if so, what the adjustment speed is with which a firm moves toward its target ${ }^{2}$. Changes in the debt ratio $\left(D_{i t}-D_{i t-1}\right)$ partially absorb the difference between target leverage $\left(D_{i t}{ }^{*}\right)$ and lagged leverage $\left(D_{i t-1}\right)$.

$$
\left(D_{i t}-D_{i t-1}\right)=\alpha\left(D_{i t}^{*}-D_{i t-1}\right)
$$

where the transaction costs that impede a complete adjustment to the target leverage are measured by the coefficient $\alpha$, which varies between 0 and 1 and is inversely related to adjustment costs.

As the target debt is unobservable, we model it as a linear function of the determining factors of capital structure reviewed in the previous section.

\footnotetext{
${ }^{2}$ Results consistent with a partial adjustment to the target leverage have been obtained for US firms (Jalilvand and Harris, 1984; Fischer et al., 1989; Shyam-Sunder and Myers, 1999; Fama and French, 2002; Flannery and Rangan,
} 


$$
D_{i t}^{*}=a_{0}+a_{1} N D T S_{i t}+a_{2} \text { PROF }_{i t}+a_{3} \text { RROWTH }_{i t}+a_{4} I N T A N G_{i t}+\mu_{i t}
$$

where $D *{ }_{i t}$ is the target leverage of firm $i$ in year $t$ and its explanatory variables are the non-debt tax shields (NDTS), profitability (PROF), growth opportunities (GROWTH) and the intangibility of the firm's assets (INTANG).

Incorporating Eq. (2) into Eq. (1) and considering that estimations were carried out with panel data, we get:

$$
\begin{aligned}
D_{i t}= & \alpha a_{0}+(1-\alpha) D_{i t-1}+\alpha a_{1} N D T S_{i t}+\alpha a_{2} \text { PROF }_{i t}+\alpha a_{3} \text { GROWTH }_{i t}+ \\
& +\alpha a_{4} I N T A N G_{i t}+\sum_{t=1995}^{2003} Y_{t}+\sum_{j=1}^{n} I_{j}+\gamma_{i}+\mu_{i t}
\end{aligned}
$$

where $\sum_{t=1995}^{2003} Y_{t}$ is a set of dummy time variables for each year capturing any unobserved firminvariant time effect not included in the regression. We also include industry dummy variables according to SIC codes $\left(\sum_{j=1}^{n} I_{j}\right)$ to capture any industry effect not included in the explanatory variables; $\gamma_{i}$ is the firm effect, which is assumed constant for firm i over $\mathrm{t}$; and $\mu_{i t}$ is the error term.

In the estimations, we apply the generalized-method-of-moments (GMM) estimators developed for dynamic models of panel data by Arellano and Bond (1991). This methodology is specifically designed to address three econometric issues: (1) the presence of unobserved firm-specific effects; (2) the autoregressive process in the data as regards the behaviour of leverage ratio; and (3) the likely endogeneity of the explanatory variables. The consistency of the GMM estimator depends on the validity of the instruments. To address this issue, we consider two specification tests suggested by Arellano and Bond (1991). The first is a Sargan test of over-identifying restrictions which tests the overall validity of the instruments by analyzing the sample analog of the moment conditions used in the estimation process. This test confirms the absence of correlation between the 
instruments and the error term in our models. The second test examines the hypothesis of lack of second-order serial correlation in the first difference residuals $\left(m_{2}\right)$. In our models, this hypothesis of second-order serial correlation is always rejected. Although there is first-order serial correlation $\left(m_{1}\right)$ in the differentiated residuals, it is due to the first difference of models.

\subsection{Database}

The partial adjustment model of firm leverage described in Equation [3] is estimated in a sample of Spanish firms over the period 1995-2003. ${ }^{3}$ The financial data are obtained from SABI, which is a database that contains financial information on public limited companies. We exclude: (1) financial firms, because their financing decision follows other determinants; (2) firms with less than 10 employees (these are considered as micro-enterprises according to European Union criteria); and (3) firms for which data required in our analyses were unavailable. Finally, the number of firms included in the sample is 3,439 and the sample consists of 16,284 firm-year observations.

As a measure of firm leverage, we use the ratio between the book value of debt (both long-term and short-term) and the book value of total assets. This measure provides a good indication of financial leverage, given that total liabilities also includes items like accounts payable, which may be used for transaction purposes rather than for financing (Rajan and Zingales, 1995), and has been used, among others, by Flannery and Rangan (2006).

We split the sample into small, medium-sized and large enterprises applying the criteria of firm size defined by the European Union in the Commission Recommendation of $3^{\text {rd }}$ April 1996 $(96 / 280 / \mathrm{EC}){ }^{4}$

2001).

${ }^{3}$ Financial data for this period has a similar format and allow us to make comparisons across firms of different sizes. After 2004, the format of financial data changed due to the adoption of the International Accounting Standards.

${ }^{4}$ A small firm is defined as an enterprise that has fewer than 50 employees but more than 10 , and has either an annual turnover not exceeding seven million euros or an annual balance-sheet total not exceeding five million euros. Mediumsized firms are defined as enterprises that have between 50 and 249 employees, and have either an annual turnover not exceeding 40 million euros, or an annual balance-sheet total not exceeding 27 million euros. Firms that exceed these limits are considered large firms. 
In Table 1 we can observe that the mean leverage ratio for the total sample is 29.54 percent, with an average profitability of 10.82 percent and a mean growth rate of total assets of 10.97 percent. However, these values vary according to firm size. Large firms show a higher leverage ratio, profitability and growth rate of assets than small firms. The differences in these variables among small, medium-sized and large firms are likewise significant when using a $t$-test such as the Wilcoxon signed-rank test in Panel B of Table 1. The differences in NDTS and INTANG between small and large firms are also significant according to the two tests.

\section{(INSERT TABLE 1 ABOUT HERE)}

Table 2 reports the correlation matrix. Debt ratio correlates positively with firm size, growth opportunities and intangible assets, whereas it correlates negatively with the amount of non-debt tax shield and firm's profitability.

\section{(INSERT TABLE 2 ABOUT HERE)}

\section{Results}

Table 3 shows the results of the partial adjustment model [3] for the entire sample of firms. Column (1) contains the estimates of the basic model without controlling for size, while columns (2), (3) and (4) control for three different size measures, namely, the natural logarithm of total assets, sales and number of employees, respectively. In all the estimates, we control for the industry by introducing a dummy variable for each industry, and for time effects by including a dummy variable for each year. All the variables are considered endogenous and are estimated in first differences, except the industry dummies. The coefficients of time and industry dummies are not reported in the tables so as to save space.

The results partially support both the TOT and the POT. We obtain two results consistent with the predictions of the TOT. First, NDTS has a negative coefficient in column (2), suggesting that the existence of non-debt tax shields reduces the tax-advantage from debt and thus also reduce the use 
of debt. Second, the positive and statistically significant coefficients of $\mathrm{DEBT}_{\mathrm{t}-1}$ suggest that the firms have a target leverage to which they partially adjust in each period. Our results show that the value of the coefficient that accompanies the variable $\mathrm{DEBT}_{\mathrm{t}-1}$ takes values of around 0.60 , which implies values of $\alpha$ of approximately $0.40 .^{5}$

While the negative coefficient of NDTS and the existence of a partial adjustment to the target leverage support the arguments of the TOT, the negative coefficient of PROFIT and the positive coefficients of GROWTH and INTANG are consistent with the predictions of the POT. Under the POT, higher profitability increases the possibility of retaining earnings and reduces the need for debt, whereas greater growth opportunities, all else being equal, increase the need for debt. Moreover, as intangible assets originate greater information asymmetries than tangible assets, the preference for debt relative to equity would increase with the percentage of intangible assets in the firm under the POT.

These results in Spanish firms constitute greater support for the POT than is generally found in prior studies for other countries. Although studies in other countries coincide in reporting a negative relation between profitability and debt, they differ in their findings in that the intangibility of assets and growth opportunities are usually negatively associated with firm leverage (Titman and Wessels, 1988; Rajan and Zingales, 1995; Fama and French, 2002; Frank and Goyal, 2003; Flannery and Rangan, 2006; Gaud et al. 2005). The greater support obtained for the POT with respect to other studies is consistent with the inclusion in the present study of small firms, if the POT has more validity in this type of firm.

Firm size, measured by LN(TA) and LN(EMP), has the traditional positive impact on leverage that has been documented in many empirical studies for other countries (Rajan and Zingales, 1995; Fama and French, 2002; Frank and Goyal, 2003; Flannery and Rangan, 2006; Gaud et al., 2005; and López-Iturriaga and Rodríguez-Sanz, 2008).

\footnotetext{
${ }^{5}$ Flannery and Rangan (2006) show that the average US firm converges toward its target at a rate of $30 \%$ per year.
} 


\section{(INSERT TABLE 3 ABOUT HERE)}

The estimation of the model [3] as a function of firm size is reported in Table 4. The first three columns in Table 4 show the results obtained separately for small, medium-sized and large firms. In accordance with the results reported above, the coefficient associated with the variable DEBT $\mathrm{t}_{-1}$ is positive and statistically significant and takes similar values regardless of firm size. The variable NDTS has negative and statistically significant coefficients in the case of small and medium-sized firms. These negative coefficients are consistent with the TOT and suggest that smaller-sized firms are the ones that use debt for tax reasons. The remaining variables, PROFIT, GROWTH and INTANG, present coefficients consistent with the POT, especially for small firms. The variable PROFIT presents negative coefficients in line with the fact that firms with higher profitability use less debt due to the greater possibility of using retained earnings. The positive coefficients of GROWTH for small firms is consistent with the fact that greater growth opportunities, ceteris paribus profitability, increases the need for debt. The positive coefficient of INTANG supports the prediction of the POT that firms with more intangible assets are subject to higher information asymmetries and that they will issue debt rather than equity if retained earnings are not sufficient. The greater positive influence of intangible assets and growth opportunities and the greater negative influence of profitability on the debt ratio in the case of small firms compared to medium-sized and large firms would be consistent with the predominance of the predictions of the POT in small firms.

We define a dummy variable, SMALL, that takes a value of 1 for small firms and 0 otherwise, which interacts with the remaining explanatory variables and enables us to analyze whether there are statistically significant differences across size groups. In this specification, the coefficients of the interaction terms indicate the differences in the respective explanatory variable in small firms with respect to the remaining firms. On the other hand, the coefficients of the explanatory variables now show the influence that they have on firm leverage for those firms that are not small in size. 
Thus, in column (4) we compare small firms versus medium-sized and large firms and in column (5) we exclude medium-sized firms so as to capture the differences between small and large firms.

The results of columns (4) and (5) do not indicate differences in the adjustment speed to the target leverage between small and large firms, as the coefficients of $\mathrm{DEBT}_{\mathrm{t}-1}$ *SMALL are not statistically significant. However, the coefficients of NDTS*SMALL are negative and statistically significant, revealing that the tax benefit of debt is more important in small than in large firms in determining the leverage ratio.

The remaining interaction terms present coefficients that are consistent with the hypothesis of a greater validity of the predictions of the POT in small firms. The coefficients of GROWTH*SMALL and INTANG*SMALL are positive and statistically significant, whereas the coefficients of GROWTH and INTANG are not statistically significant. These results indicate that growth opportunities and intangible assets are positively related to firm leverage only in small firms. Likewise consistent with a greater validity of the POT in small firms, we observe that the negative influence of profitability on leverage is heightened in small firms, as PROFIT*SMALL has negative statistically significant coefficients.

(INSERT TABLE 4 ABOUT HERE)

\section{Conclusions}

This paper analyzes whether the validity of the TOT and the POT to explain firm capital structure varies with firm size. Results are partially consistent with both explanations in Spanish firms. Consistent with the TOT, firms have a target leverage to which they adjust in each period, using more debt as the tax advantages of debt grow. Consistent with the POT, firm leverage is positively related to investment opportunities and the percentage of intangible assets, and negatively related to profitability. 
Furthermore, our results indicate that the predominance of the TOT and the POT varies across firm size. The positive relationship of firm leverage with investment opportunities and intangible assets and the negative relation with firm profitability are stronger in small firms than in medium-sized and large firms. This evidence is consistent with the hypothesis that the higher information asymmetries in small firms originate a greater validity of the pecking order theory in this type of firm. Despite the greater validity of the pecking order predictions in small firms, there are no differences in the adjustment speed to the target leverage across firms with a different size.

Our results highlight the convenience of controlling for firm size when testing the validity of explanatory theories of firm capital structure and have important policy implications. The paper suggests the relevance of bank development to facilitate the access of small firms to external financing. A greater development of the banking system that increases screening and monitoring of debtors by banks will be especially useful to reduce the greater information asymetries of small firms. As a consequence, a challenge for policy makers would be to provide both regulations and institutions that favor a greater development of the banking system as the presence of small firms increases. Moreover, regulations that facilitate close lending relationships between banks and firms will also be more beneficial to reduce the funding cost in economies with a greater presence of small firms.

Acknowledgements: We are grateful to an anonymous referee and the editor for their helpful comments and suggestions. Financial support from the Ministry of Science and Innovation of Spain - ERDF, Project MICINN-09-ECO2009-11758 is gratefully acknowledged.

\section{References}

Ang, J.S.; J.H. Chua and J.J. McConnell (1982): "The administrative costs of corporate bankruptcy: A note". Journal of Finance 37, pp. 337-348.

Arellano, M. and S. Bond (1991): "Some tests of specification for panel data: Monte Carlo evidence and an application to employment equations". Review of Economic Studies 58, pp. 277-297. 
Colombo, E. (2001): "Determinants of corporate capital structure: evidence from Hungarian firms". Applied Economics, 33 (13), pp. 1689-1701.

Fama, E.F. and K.R. French (2002): "Testing trade-off and pecking order predictions about dividends and debt". The Review of Financial Studies 15 (1), pp. 1-33.

Ferri, M. and W. Jones (1979): "Determinants of financial structure: a new methodological approach". Journal of Finance 34, pp. 631-644.

Fischer, E.O.; R. Heinkel and J. Zechner (1989): "Dynamic capital structure choice: theory and tests". Journal of Finance 44 (1), pp. 19-40.

Flannery, M.J. and K.P. Rangan (2006): "Partial adjustment toward target capital structures". Journal of Financial Economics, 79 (3), pp. 469-506.

Frank, M. and V.K. Goyal (2003): "Testing the pecking order theory of capital structure". Journal of Financial Economics 67, pp. 217-248.

Gaud, P.; E. Jani; M. Hoesli and A. Bender (2005): "The capital structure of Swiss companies: An empirical analysis using dynamic panel data". European Financial Management 11 (1), pp. 51-69.

Graham, J.R. (2000): “How big are the tax benefits of debt?”. Journal of Finance 55, pp. 1901-1940.

Grinblatt, M. and S. Titman (1998): Financial markets and corporate strategy. International edition (Boston: McGraw-Hill).

Harris, M. and A. Raviv (1991): "The theory of capital structure". Journal of Finance 46, pp. 297-355.

Jalilvand, A. and R.S. Harris (1984): "Corporate behavior in adjusting to capital structure and dividend targets: an econometric study". Journal of Finance 39, pp. 127-145.

Jensen, M. (1986): "Agency cost of free cash flow, corporate finance and takeovers". American Economic Review 76 (2), pp. 323-329.

Jung, K.; Y. Kim and R. Stulz (1996): "Timing, investment opportunities, managerial discretion, and the security issue decision". Journal of Financial Economics 42, pp. 159-185.

Leary, M. and M. Roberts (2005): "Do firms rebalance their capital structure?". Journal of Finance 60 (6), pp. 2575-2619.

López-Iturriaga, F.J. and J.A. Rodríguez-Sanz (2008): “Capital structure and institutional setting: a decompositional and international analysis”. Applied Economics 40 (14), pp. 1851-1864.

Miguel, A. de and J. Pindado (2001): "Determinants of capital structure: new evidence from Spanish panel data". Journal of Corporate Finance 7, pp. 77-99.

Myers, S. (1977): "Determinants of corporate borrowing". Journal of Financial Economics 5 (2), pp. 147-175.

Myers, S. (1984): “The capital structure puzzle”. Journal of Finance 34, pp. 575-592.

Myers, S. and N. Majluf (1984): "Corporate financing and investment decisions when firms have information that investors don't have". Journal of Financial Economics 13 (2), pp. 187-221.

Ozkan, A. (2001): "Determinants of capital structure and adjustment to long run target: Evidence from UK company panel data”. Journal of Business, Finance \& Accounting 28 (1), pp. 175-198.

Rajan, R.G. and L. Zingales (1995): "What do we know about capital structure? Some evidence from international data". Journal of Finance 50 (5), pp. 1421-1460.

Shyam-Sunder, L. and S.C. Myers (1999): "Testing static tradeoff against pecking order models of capital structure". Journal of Financial Economics 51, pp. 219-244.

Smith, C.W. and R. Stulz (1985): "The determinants of firm's hedging policies". Journal of Financial and Quantitative Analysis 20, pp. 391-405.

Titman, S. and R. Wessels (1988): "The determinants of capital structures choice". Journal of Finance 43, pp. 1-19.

Tong, G. and C.J. Green (2005): "Pecking order or trade-off hypothesis? Evidence on the capital structure of Chinese companies". Applied Economics 37 (19), pp. 2179-2189.

Warner, J.B. (1977): "Bankruptcy costs: some evidence". Journal of Finance 32, pp. 337-348.

$\mathrm{Yu}$, D.D. and R.Q. Aquino (2009): "Testing capital structure models on Philippine listed firms". Applied Economics 41 (15), pp. 1973-1990. 
Table 1

Summary statistics

\begin{tabular}{|c|c|c|c|c|c|c|}
\hline \multicolumn{7}{|c|}{ Panel A: Descriptive statistics } \\
\hline \multirow[t]{2}{*}{ Variables } & & Mean & $\begin{array}{l}\text { Standard } \\
\text { deviation }\end{array}$ & $\begin{array}{c}\text { First } \\
\text { Quartile }\end{array}$ & Median & $\begin{array}{c}\text { Third } \\
\text { Quartile }\end{array}$ \\
\hline & & (1) & $(2)$ & (3) & (4) & $(5)$ \\
\hline \multirow{4}{*}{ DEBT $(\%)$} & Total sample & 29.54 & 21.00 & 12.51 & 27.97 & 42.89 \\
\hline & Small firms & 26.51 & 21.35 & 9.09 & 23.98 & 39.59 \\
\hline & Medium firms & 29.68 & 20.65 & 13.29 & 28.09 & 42.93 \\
\hline & Large firms & 30.93 & 21.31 & 13.30 & 29.51 & 44.59 \\
\hline \multirow{4}{*}{ NDTS $(\%)$} & Total sample & 0.26 & 13.75 & 0.00 & 0.14 & 1.41 \\
\hline & Small firms & -0.06 & 15.65 & -0.04 & 0.01 & 0.88 \\
\hline & Medium firms & 0.16 & 15.83 & 0.00 & 0.16 & 1.48 \\
\hline & Large firms & 0.64 & 6.30 & 0.00 & 0.19 & 1.52 \\
\hline \multirow{4}{*}{ PROFIT (\%) } & Total sample & 10.82 & 15.36 & 6.00 & 10.32 & 15.88 \\
\hline & Small firms & 8.53 & 16.23 & 4.39 & 8.83 & 13.83 \\
\hline & Medium firms & 11.04 & 17.15 & 6.26 & 10.65 & 16.18 \\
\hline & Large firms & 11.65 & 10.26 & 6.28 & 10.59 & 16.16 \\
\hline \multirow{4}{*}{ GROWTH (\%) } & Total sample & 10.97 & 28.49 & -2.30 & 6.74 & 19.09 \\
\hline & Small firms & 6.43 & 27.46 & -5.59 & 3.52 & 14.79 \\
\hline & Medium firms & 10.47 & 26.30 & -2.26 & 6.54 & 18.48 \\
\hline & Large firms & 14.40 & 32.41 & -0.56 & 9.05 & 22.27 \\
\hline \multirow{7}{*}{ INTANG (\%) } & Total sample & 4.50 & 8.43 & 0.17 & 1.17 & 4.71 \\
\hline & Small firms & 4.59 & 9.21 & 0.09 & 1.02 & 4.66 \\
\hline & Medium firms & 4.63 & 8.46 & 0.20 & 1.22 & 4.89 \\
\hline & Large firms & 4.19 & 7.91 & 0.17 & 1.14 & 4.33 \\
\hline & \multicolumn{4}{|c|}{ Panel B: Mean differences } & & \\
\hline & \multicolumn{2}{|c|}{$\begin{array}{l}\text { Small vs. medium } \\
\text { (1) }\end{array}$} & \multicolumn{2}{|c|}{$\begin{array}{c}\text { Small vs. large } \\
\text { (2) }\end{array}$} & \multicolumn{2}{|c|}{$\begin{array}{c}\text { Medium vs. large } \\
\text { (3) }\end{array}$} \\
\hline & t-test & $\begin{array}{c}\text { Wilcoxon } \\
\text { test }\end{array}$ & t-test & $\begin{array}{c}\text { Wilcoxon } \\
\text { test }\end{array}$ & t-test & $\begin{array}{c}\text { Wilcoxon } \\
\text { test }\end{array}$ \\
\hline DEBT & $-6.819 * * *$ & $-5.899 * * *$ & $-8.466 * * *$ & $-8.282 * * *$ & $-3.352 * * *$ & $-2.742 * * *$ \\
\hline NDTS & -0.618 & $-5.986 * * *$ & $-2.191 * * *$ & $-6.991 * * *$ & $-2.568 * * *$ & $-2.672 * * *$ \\
\hline PROFIT & $-6.824 * * *$ & $-7.514 * * *$ & $-8.815 * * *$ & $-8.106 * * *$ & $-2.596 * * *$ & $-2.289 * * *_{-}$ \\
\hline GROWTH & $-6.641 * * *$ & $-6.897 * * *$ & $-11.078 * * *$ & $-11.695 * * *$ & $-7.170 * * *$ & $-5.964 * * *$ \\
\hline INTANG & -0.195 & -0.452 & $1.838^{* *}$ & $1.653 *$ & $2.988 * * *$ & 0.329 \\
\hline
\end{tabular}

$* * *, * *$ and $*$ represent the significance at the 1 percent, 5 percent and 10 percent level, respectively. 
Table 2

Correlations

\begin{tabular}{|c|c|c|c|c|c|c|c|}
\hline & DEBT & $\mathrm{LN}(\mathrm{TA})$ & LN(SALES) & LN(EMP) & NDTS & PROFIT & GROWTH \\
\hline LN(TA) & $0.1144 * * *$ & & & & & & \\
\hline LN(SALES) & $0.0148 * *$ & $0.8337 * * *$ & & & & & \\
\hline LN(EMP) & $0.0338 * * *$ & $0.7064 * * *$ & $0.7834 * * *$ & & & & \\
\hline NDTS & $-0.01611 * * *$ & $0.0066^{*}$ & $0.0280 * * *$ & $0.0108 * *$ & & & \\
\hline PROFIT & $-0.01792 * * *$ & $0.0478 * * *$ & $0.0393 * * *$ & $0.0196 * * *$ & $0.0600 * * *$ & & \\
\hline GROWTH & $0.0401 * * *$ & $0.1208 * * *$ & $0.0612 * * *$ & $0.0496 * * *$ & $0.0116^{* * *}$ & $0.0361 * * *$ & \\
\hline INTANG & $0.1538 * * *$ & $-0.0392 * * *$ & $-0.0502 * * *$ & $-0.0197 * * *$ & -0.0011 & $0.0164 * * *$ & $0.0343 * * *$ \\
\hline
\end{tabular}

***, ** and * represent the significance at the 1 percent, 5 percent and 10 percent level, respectively. 
Table 3

Determinants of firm leverage

\begin{tabular}{|c|c|c|c|c|c|c|}
\hline \multicolumn{7}{|c|}{ Predicted sign } \\
\hline & TOT & POT & $(1)$ & (2) & (3) & (4) \\
\hline INTERCEPT & & & $\begin{array}{l}0.0113^{* *} \\
(2.01)\end{array}$ & $\begin{array}{l}0.0068 \\
(1.21)\end{array}$ & $\begin{array}{l}0.0110^{*} \\
(1.90)\end{array}$ & $\begin{array}{l}0.0061 \\
(0.97)\end{array}$ \\
\hline DEBTt-1 & + & & $\begin{array}{l}0.6382 * * * \\
(26.30)\end{array}$ & $\begin{array}{l}0.5942 * * * \\
(23.36)\end{array}$ & $\begin{array}{l}0.6357^{* * * *} \\
(29.56)\end{array}$ & $\begin{array}{l}0.6429 * * * \\
(23.85)\end{array}$ \\
\hline NDTS & - & & $\begin{array}{l}-0.0343 \\
(-0.59)\end{array}$ & $\begin{array}{l}-0.1207^{* *} \\
(-1.98)\end{array}$ & $\begin{array}{l}-0.0268 \\
(-0.45)\end{array}$ & $\begin{array}{l}-0.0311 \\
(-0.49)\end{array}$ \\
\hline PROFIT & + & - & $\begin{array}{l}-0.1544 * * * \\
(-2.76)\end{array}$ & $\begin{array}{l}-0.0743 \\
(-1.25)\end{array}$ & $\begin{array}{l}-0.1226^{* *} \\
(-2.03)\end{array}$ & $\begin{array}{l}-0.1045^{*} \\
(-1.65)\end{array}$ \\
\hline GROWTH & - & + & $\begin{array}{l}0.0497 * * \\
(2.32)\end{array}$ & $\begin{array}{l}0.0321 * * \\
(2.02)\end{array}$ & $\begin{array}{l}0.0300 \\
(1.32)\end{array}$ & $\begin{array}{l}0.0211 \\
(0.96)\end{array}$ \\
\hline INTANG & - & + & $\begin{array}{l}0.0905 \\
(1.46)\end{array}$ & $\begin{array}{l}0.0538 \\
(0.82)\end{array}$ & $\begin{array}{l}0.1133^{*} \\
(1.79)\end{array}$ & $\begin{array}{l}0.0979 * * \\
(1.42)\end{array}$ \\
\hline LN(TA) & + & $+/-$ & & $\begin{array}{l}0.1974 * * * \\
(4.42)\end{array}$ & & \\
\hline LN(SALES) & + & $+/-$ & & & $\begin{array}{l}-0.0065 \\
(-0.48)\end{array}$ & \\
\hline LN(EMP) & + & $+/-$ & & & & $\begin{array}{l}0.0236^{*} \\
(1.85)\end{array}$ \\
\hline Time dummies & & & Yes & Yes & Yes & Yes \\
\hline Industry dummies & & & Yes & Yes & Yes & Yes \\
\hline $\mathrm{m}_{1}$ & & & $-9.57 * * *$ & $-11.06 * * *$ & $-9.71 * * *$ & $-8.51 * * *$ \\
\hline $\mathrm{m}_{2}$ & & & -0.23 & -0.53 & -0.10 & 0.79 \\
\hline Sargan Test & & & 152.77 & $160.22 * *$ & 155.30 & 152.50 \\
\hline \# observations & & & 16284 & 16284 & 16246 & 14242 \\
\hline \# firms & & & 3439 & 3439 & 3430 & 3308 \\
\hline
\end{tabular}

$t$-statistics in parentheses. $* * *, * *$ and $*$ represent the significance at the $1 \%, 5 \%$ and $10 \%$ level, respectively. 
Table 4

Firm size and determinants of leverage

\begin{tabular}{|c|c|c|c|c|c|c|c|}
\hline & \multicolumn{2}{|c|}{ Predicted sign } & \multirow{2}{*}{$\begin{array}{c}\text { Small } \\
(1)\end{array}$} & \multirow{2}{*}{$\begin{array}{c}\text { Medium } \\
(2)\end{array}$} & \multirow{2}{*}{$\begin{array}{c}\text { Large } \\
(3)\end{array}$} & \multirow{2}{*}{$\begin{array}{c}\text { Small vs. } \\
\text { medium } \\
\text { and large }\end{array}$} & \multirow{2}{*}{$\begin{array}{c}\text { Small vs. } \\
\text { large }\end{array}$} \\
\hline & TOT & POT & & & & & \\
\hline $\begin{array}{l}\text { INTERCEPT } \\
\text { DEBTt-1 }\end{array}$ & + & & $\begin{array}{c}0.0145 \\
(0.89) \\
0.4366^{* * *} \\
(11.77)\end{array}$ & $\begin{array}{c}0.0155^{* *} \\
(2.21) \\
0.5467 * * * \\
(18.93)\end{array}$ & $\begin{array}{c}0.0002 \\
(0.03) \\
0.4958^{* * *} \\
(13.92)\end{array}$ & $\begin{array}{c}0.0109^{* *} \\
(2.17) \\
0.5804^{* * *} \\
(26.55)\end{array}$ & $\begin{array}{c}0.0021 \\
(0.27) \\
0.5806^{* * *} \\
(23.69)\end{array}$ \\
\hline NDTS & - & & $\begin{array}{c}-0.1465 * * * \\
(-2.90)\end{array}$ & $\begin{array}{c}-0.2775 * * * \\
(-4.26)\end{array}$ & $\begin{array}{l}-0.0577 \\
(-0.67)\end{array}$ & $\begin{array}{l}-0.0154 \\
(-0.32)\end{array}$ & $\begin{array}{c}-0.1179^{*} \\
(-1.75)\end{array}$ \\
\hline PROFIT & + & - & $\begin{array}{c}-0.1591 * * \\
(-2.44)\end{array}$ & $\begin{array}{c}0.1190^{*} \\
(1.86)\end{array}$ & $\begin{array}{c}-0.2892 * * * \\
(-3.73)\end{array}$ & $\begin{array}{c}-0.1442 * * * \\
(-3.05)\end{array}$ & $\begin{array}{c}-0.2598 * * * \\
(-4.65)\end{array}$ \\
\hline GROWTH & - & + & $\begin{array}{l}0.0315^{* * *} \\
(2.65)\end{array}$ & $\begin{array}{l}-0.0295 \\
(-1.20)\end{array}$ & $\begin{array}{c}0.0299 * * \\
(2.29)\end{array}$ & $\begin{array}{l}0.0149 \\
(1.02)\end{array}$ & $\begin{array}{l}0.0027 \\
(0.20)\end{array}$ \\
\hline INTANG & - & + & $\begin{array}{l}0.8874^{* * *} \\
(8.42)\end{array}$ & $\begin{array}{l}0.1250 \\
(1.48)\end{array}$ & $\begin{array}{l}0.0076 \\
(0.08)\end{array}$ & $\begin{array}{l}0.0738 \\
(1.27)\end{array}$ & $\begin{array}{l}0.1076 \\
(1.50)\end{array}$ \\
\hline DEBTt-1 $*$ SMALL & & & & & & $\begin{array}{c}-0.0005 \\
(-0.02)\end{array}$ & $\begin{array}{c}0.0287 \\
(1.23)\end{array}$ \\
\hline $\begin{array}{l}\text { NDTS * SMALL } \\
\text { PROFIT * SMALL }\end{array}$ & & & & & & $\begin{array}{c}-0.3692 * * * \\
(-4.56) \\
-0.1868 * * * \\
(-2.87)\end{array}$ & $\begin{array}{c}-0.4252^{* * *} \\
(-4.49) \\
-0.2008^{* * *} \\
(-3.16)\end{array}$ \\
\hline GROWTH * SMALL & & & & & & $\begin{array}{l}0.1118^{* * *} \\
(6.27)\end{array}$ & $\begin{array}{c}0.1008 * * * \\
(6.73)\end{array}$ \\
\hline INTANG * SMALL & & & & & & $\begin{array}{c}0.2289 * * * \\
(2.77) \\
\text { Yes }\end{array}$ & $\begin{array}{c}0.2237 * * * \\
(2.76) \\
\text { Yes }\end{array}$ \\
\hline $\begin{array}{l}\text { Time dummies } \\
\text { Industry dummies }\end{array}$ & & & & & & Yes & Yes \\
\hline $\mathrm{m}_{1}$ & & & $-5.99^{* * *}$ & $-10.02 * * *$ & $-10.16^{* * *}$ & $-9.33 * * *$ & $-11.62 * * *$ \\
\hline $\mathrm{m}_{2}$ & & & -0.89 & -0.48 & 0.23 & -0.25 & 1.24 \\
\hline Sargan Test & & & $161.59^{*}$ & 152.69 & 146.02 & 287.58 & 271.06 \\
\hline \# observations & & & 2518 & 9011 & 4755 & 16155 & 6175 \\
\hline \# firms & & & 928 & 2160 & 1330 & 3418 & 1651 \\
\hline
\end{tabular}

$t$-statistics in parentheses. $* * *, * *$ and $*$ represent the significance at the $1 \%, 5 \%$ and $10 \%$ level, respectively. 